\title{
Identity of the Brazilian species Dioscorea pumilio Griseb. and its synonyms
}

\author{
Cecilia Carmen Xifreda ${ }^{1}$ and $\stackrel{\text { Mizue Kirizawa }}{2,3}$
}

Received: 19.03.2018; accepted: 11.07.2018

\begin{abstract}
Identity of the Brazilian species Dioscorea pumilio Griseb. and its synonyms). Dioscorea pumilio, a dwarf species, was originally described by Grisebach in 1875 based on staminate material only, which was obtained from a few flowered and floral bud collection made by A. Glaziou. The diagnosis and the drawings with the author's handwriting in the exsiccates deposited at the Göttingen Herbarium (GOET), and the isotypes at the Herbaria of Paris (P), Copenhagen (C) and Berlin (B), are enough to elucidate the identity of the species. Two synonyms of Dioscorea pumilio, D. beyrichii and $D$. sphaeroidea, are proposed here. All three names were based upon type materials collected at the same site of the "Parque Nacional da Serra dos Órgãos", Brazil. A brief comment about the systematic implications is also included.

Keywords: Atlantic Forest, Brazil, Dioscoreaceae, seeds, synonymy
\end{abstract}

RESUMO - (Identidade da espécie brasileira Dioscorea pumilio Griseb. e seus sinônimos). Dioscorea pumilio, uma espécie anã, foi descrita por Grisebach em 1875 a partir de único material estaminado obtido de uma coleção de umas poucas flores e botão floral realizada por A. Glaziou. A diagnose e os desenhos nas exsicatas com informações manuscritas do autor, depositados no Herbário de Goettingen(GOET), mais os isotipos dos Herbários de Paris (P), Copenhague (C) e Berlin (B), são suficientes para esclarecer a identidade desta espécie. Dois sinônimos de Dioscorea pumilio, D. beyrichii e D. sphaeroidea, são aqui designados. Todos os três nomes são baseados em tipos coletados no mesmo local do Parque Nacional da Serra dos Órgãos, Brasil. É acrescentado também um breve comentário sobre implicações sistemáticas.

Palavras-chave: Brasil, Dioscoreaceae, Floresta Atlântica, sementes, sinonímias

\section{Introduction}

The detailed examination of types and the revision of valid names of Dioscoreaceae as part of the taxonomic research of Dioscoreaceae of the Brazil Flora Group -BFG (2015) allowed the identification of some forgotten or misunderstood names. In the present study, we indicated the correct name of some taxa described from the same site located near or in the proximities of the summit of the "Parque Nacional da Serra dos Órgãos", Rio de Janeiro State, Brazil. Furthermore, we cited for the first time additional material studied from "Parque Estadual do Desengano", Rio de Janeiro, Brazil.

\section{Material and methods}

The taxonomic analyses were based upon type materials of Dioscorea pumilio Griseb., D. beyrichii R. Knuth, and D. spharoidea R. Couto \& M.A. Braga obtained from exsiccates with author's handwriting deposited at the Goettingen Herbarium (GOET) and from the isotypes deposited at the Herbaria of Paris (P), Copenhaguen (C) and Berlin (B), besides studies on these species published by Grisebach (1842), Knuth $(1917,1924)$ and Couto et al. (2014). All these species of Dioscorea were collected in the same area of "Pedra do Sino", which currently belongs to "Parque Nacional da Serra dos Órgãos", a component of orographic system of Serra do Mar.

1. Instituto de Botánica Darwinion, Labardén 200, Casilla de Correo 22, San Isidro, Buenos Aires, Argentina

2. Instituto de Botânica, Núcleo de Pesquisa Curadoria do Herbário SP, Av. Miguel Stéfano 3687, 04301-902, São Paulo, SP, Brasil

3. Autor para correspondência: mkirizawa@uol.com.br 


\section{Results and Discussion}

The analysis of protologues enabled the accurate identification of Dioscorea pumilio Griseb.

Dioscorea pumilio Griseb., Kjoeb. Vidensk. Meddel.: 162. 1875. TYPE: Brazil. "Province de Rio de Janeiro", A. Glaziou 4265 (holotype GOET 006382; isotypes B! 100247759, C 10010746 , FOBN 010533, NY Neg. N.S. 4633, P! 00748429.

Dioscorea beyrichii R. Knuth, Notizbl. Bot. Gart. Berlin-Dahlem 7: 210. 1917. TYPE: Brazil. Rio de Janeiro, "in rupibus humidis montium pr. Partem Corco", febr., Serra dos Órgãos, H.K. Beyrich 3 in O. Hoffman Herbarium, staminate (holotype B! 100278752. Syn. nov.

Dioscorea sphaeroidea R. Couto \& J.M.A. Braga, Phytotaxa 163 (4): 230. 2014. TYPE: Brazil, Rio de Janeiro, Teresópolis, Parque Nacional da Serra dos Órgãos, Pedra do Sino, $2.200 \mathrm{~m}$ a.s.1., 22 27'44.3”S and $43^{\circ} 01$ '51,6”W, 31-III- 2010, R.S. Couto et al. 316 (holotype RB!; isotype R not examined); Teresópolis, Parque Nacional da Serra dos Órgãos, Pedra do Sino, near the mountain summit, $2.200 \mathrm{~m}$ a.s.1., $22^{\circ} 27^{\prime} 44.3^{\prime \prime S}$, and $43^{\circ} 01^{\prime} 51.6^{\prime \prime} \mathrm{W}, 31-\mathrm{III}-2010$, R.S. Couto et al. 317 (paratype RB!); Teresópolis, Parque Nacional da Serra dos Órgãos, Pedra do Sino, $2.216 \mathrm{~m}$ a.s.1., $22^{\circ} 27^{\prime} 44.3^{\prime \prime} S$ and $43^{\circ} 01^{\prime}$ '51.6'W, 22-III- 2007, M. Nadruz et al. 1782 (paratype RB!). Syn. nov.

Additional material studied: Brazil, Rio de Janeiro, Município de Santa Maria Madalena, Parque Estadual do Desengano, trail to Pedra do Desengano, 25-III-2002, P. Fiaschi et al. 1023 (SPF).

Observations: although the type material of D. pumilio at Berlin only mentioned Rio de Janeiro, the isotype conserved at Paris referred "Sommet des Orgãos", 12-X-1869, male. On the other hand, in Beyrich 3 the collection site of $D$. beyrichii was annotated as "Partem Corco": Corco might be an apocope of the Portuguese word "corcova" that means hump, properly describing the top of the mountain at "Pedra do Sino", which means bell's stone.

The occurrence of $D$. pumilio in the Desengano National Park, 1.200-1.761 m a.s.1., $21^{\circ} 40^{\prime}-22^{\circ} 10^{\prime}$ S and $41^{\circ} 20^{\prime}-42^{\circ} 10^{\prime} \mathrm{W}$ (INEA-Instituto Terra Brasil 2011) increases the range of distribution of D. pumilio near 1 degree of longitude East and ca. 8 degrees of latitude North.

The morphological characteristics of these conspecific entities are very similar. Grisebach (1842) characterized $D$. pumilio by its dwarf habit and filiform stem, creeping in the basal region; leaves cordateovate, deltoid, with an acute tip, 7-nerved, the two outer nerves bifurcate, with prominent veins below, becoming black when dried, almost glabrous; 6-parted perianth with roundish segments; three stamens, extrorse, inserted at the mouth of perianth; perianth tube very short. Knuth (1924) described D. beyrichii as a twining plant of $30 \mathrm{~cm}$ tall, with a glabrous and filiform stem; alternate leaves, $3-5 \mathrm{~cm}$ distant from each other, blade 2-3 $(-4) \mathrm{cm} \times 3-4 \mathrm{~cm}$; basal leaves shorter and wider, papyraceous, lanceolates, narrowing towards the apex, acute or slightly acute, sinus cordate, almost acute, (5)-7 nerved, glabrous. Staminate flowers with rotate perianth, $3 \mathrm{~mm}$ diam., parted until its middle; roundish tepals, triquetrous, $1 \mathrm{~mm}$ long, apex weakly obtuse; three stamens inserted at base of tube, anthers sessile. Flowering time: February.

Finally, D. sphaeroidea was recognized as a dwarf plant with creeping branches, small discoid tubers, staminate flowers with three stamens and a flattened pistillode.

The main differences between the type materials of $D$. pumilio Griseb. and $D$. beyrichii $\mathrm{R}$. Knuth is that the former plant stands strictly erect while the second is a dwarf plant with twinning stems. The condition was explained by Burkill (1960), for dwarf dioscoreas growing in grasslands, no taller - than the associated grasses; but if it chances to be where the soil is good enough to support a bush, it profits by the increased moisture and shade to be just tall enough to twine. On the other hand, Schubert (1966) in her publication mentioned the expected difficulties while studying species of Dioscorea. She commented the results based upon mixed collections for which specimens of both sexes were not available, and therefore the species were described from only specimens of one sex. At the time D. pumilio was described, the original material had not fruits. The first pistillate collection assigned to the species was Nadruz et al. 1782 (RB), published by Couto et al. (2014), which was considered by these authors as a new species, $D$. spharoidea. Due to the presence of a rounded fruit and a spherical wingless seed, these authors concluded that the infrageneric position of this species is uncertain and consequently, the assignment to a subgenus or a section was not possible.

The presence of wingless spherical seeds in a Dioscorea species is not a novelty. Burkill (1960) pointed out that dwarf plants of Dioscorea might lose 
the seed wings, giving examples and explanations.

The infrageneric subdivision of Dioscorea into subgenera is based on the characteristics of the seeds. The sectional delimitation was first provided by Grisebach (1842) and D. pumilio was included originally in the section Allactostemon Griseb. and it was subsequently transferred to Hemidematostemon Griseb., a section pertaining to the subgenus Dioscorea, whose members have rounded seeds. However, Burkill (1960) and Knuth (1924) considered that $D$. pumilio may belong to another section of the same subgenus, Polyneuron Uline. Uline (1897) assigned six species to this section, all of them from Mexico. The characterization of this section is adequate because two dwarf plants are included there, and because in the description of $D$. multinervis Benth. Uline annotated "semina globose". This datum comes from the original diagnosis of its synonym $D$. nana Schlechtendal (1844) non Poepp. that mentioned "fructus subglobosi, trianguli, ad angulos verrucose, 2 semina globose gerentibus".

Meantime, due to its wingless seeds, D. pumilio cannot be assigned to a proper section and thus should be considered as section incertae sedis in Dioscorea L. subg. Dioscorea. This study highlights the need for revaluation of the infrageneric classification of Dioscorea, particularly in the case of sectional assignment of $D$. pumilio.

\section{Acknowledgements}

The authors are grateful to the Curators B, P, RB and SPF Herbaria for their support during visits to conduct taxonomic studies in the genus Dioscorea. CCX is grateful for the financial support provided by the Myndel Foundation Grant to travel and stay at
Berlin Museum and Botanical Garden. We also wish to thank to anonymous referees for their valuable comments.

\section{Literature cited}

BFG (The Brazil Flora Group). 2015. Growing knowledge: an overview of seed plant diversity in Brazil. Rodriguésia (on line) 66: 1-29.

Burkill, I.H. 1960. The organography and the evolution of Dioscoreaceae, the family of the yams. Botanical Journal of the Linnean Society 56: 319-412.

Couto, R.S., Lopes, R.C. \& Braga, J.M.A. 2014. Dioscorea sphaeroidea (Dioscoreaceae), a threatened new species from the high-altitude grasslands of Southeastern Brazil with wingless seeds. Phytotaxa 163: 229-234.

Grisebach, A.H.R. 1842. Dioscoreaceae. In: C.F.P. Martius \& A.G. Eichler (eds.). Flora Brasiliensis. Lipsiae, Fried Fleischer 3: 26-48.

INEA- Instituto Estadual do Ambiente do Estado do Rio de Janeiro. Instituto Terra Brasil. 2011. Trilhas: Parque Estadual do Desengano. Rio de Janeiro.

Knuth, R. 1917. I. Dioscoreaceae americanae novae. In: Notizblatt des König. Botanischen Gartens und Museums zu Berlin-Dahlem n. 65: 185-222.

Knuth, R. 1924. Dioscoreaceae. In: H.G.A. Engler (ed.) Pflanzenreich IV 43: 1-387. Wilhelm Engelmann, Leipzig.

Schubert, B.G. 1966. Studies in Dioscorea, I: A collection from British Honduras. Journal of the Arnold Arboretum 47: 147-159.

Schlechtendal, D.F.L. 1844. Supplementum ad Dioscoreas Mexicanas. Linnaea 28: 112.

Uline, E.B. 1897. Dioscoreaceae. In: H.G.A. Engler \& K.A.E. Prantl (eds.). Die Natürlichen Pflanzenfamilien Nachtrag und Register zu II: 80-87. Wilhelm Engelmann, Leipzig. 